\title{
Zkoumání (kvality) výuky: srovnání dvou př́stupů
}

\author{
Petr Najvar
}

\begin{abstract}
Abstrakt: Tato studie kontrastivně predstavuje dva antagonické prìstupy ke zkoumání edukačnich procesů ve školni výuce. Jednim z nich je tzv. IVŠV videostudie výnky jako reprezentant kvantitativních videostudii (KVS); prístup využivajici deduktivni kategoriálni systémy $k$ zachyceni obsahu a formy vyučováni a učeni a ke kvantifikujicimu zobecnèni vztaženému napr. $k$ interakčním vzorcuim ve výuce či oborovým a oborovédidaktickým specifikùm výuky. Druhým z nich je obsahově zamèrený prístup ke zkoumáni a zlepšováni výuky jako prístup stavèjici na induktivnim postupu prì identifikaci obsahových jader výnky a na kvalitativnim hodnocení didaktické kvality výukových situaci. Tyto výzkumné prìstupy jsou využity pro osvètleni rozdilì v povaze didaktického poznáni generovaného postupy stavéjicimi na tzv. predem strukturované reflexi, ve srovnáni s didaktickým poznáním, jež prìnásí tzv. následně strukturovaná reflexe výuky.
\end{abstract}

Kličová slova: výzkum výnky, videostudie, obsahově zaměrený prístup, analýza výnkových situací, predem strukturovaná reflexe, následnè strukturovaná reflexe.

Tato studie si klade za cíl prrispět k poznání některých problémů, které provázejí výzkumy kvality výuky. Výzkumy kvality výuky vycházejí z předpokladu, že je možné rozlišovat různé způsoby zprostředkování vzdělávacího obsahu a že rozdíly mezi nimi (obecněji rozdíly ve způsobu utváření učebního prostředí $\left.{ }^{1}\right)$ mohou být interpretovány jako rozdíly $\mathrm{v}$ kvalitě výuky. Předpokládá se tím také, že určité vlastnosti učebního prostředí ve výuce jsou př́inosnější pro učení žáků než vlastnosti jiné a že změna způsobu výuky s sebou nese změnu $\mathrm{v}$ přínosnosti pro žáky ( $\mathrm{tj}$. ve vzdělávací kvalitě). Kdyby tomu tak nebylo, bylo by lhostejné, jak výuka probíhá, a takové aktivity, jako je profesní př́prava učitelů, by pozbývaly smyslu. Ve skutečnosti leží naopak téma kvality výuky v jádru (oborově)didaktické složky učitelské př́ípravy.

Výzkum výuky vycházející z těchto předpokladů potom směruje $\mathrm{k}$ identifikaci a popisu horších a lepších variant výuky, přičemž v centru jeho pozornosti

\footnotetext{
${ }^{1}$ Učební prostředí chápeme jako kulturní pole, ve kterém jsou žákům nabízeny př́ležitosti k porozumění určitému obsahu prostřednictvím učebních úloh (Slavík et al., 2017, s. 296). Pojem zkoumání způsobů utvárení učebního prostředí lze v kontextu školní třídy chápat jako ekvivalentní k pojmu zkoumání výuky.
} 
jsou (didaktické) praktiky učitelů. ${ }^{2}$ Naráží při tom však na fakt, že kauzální vztahy mezi vlastnostmi učebního prostředí a jeho vlivem na jednotlivé žáky nelze př́mo pozorovat. Mưže proto být jen tak validní, jak dobře dokáže osvětlovat a překlenout "mezeru“ mezi popisem pozorovaných vlastností výuky a hodnocením jejich př́nosu pro žáky. Zaplňovat tuto mezeru má za cíl snad každé didaktické poznávání a z metodologického nadhledu se jí věnuje i tento text. Je opřen o analytické porovnání dvou odlišných výzkumných přístupů, resp. strategií. Jeden $\mathrm{z}$ nich je $\mathrm{v}$ principu deduktivní, druhý induktivní. ${ }^{3}$

Za deduktivní lze označit takovou strategii, při které je existující teorie využita pro definování kategorií (proměnných), skrze něž je na výuku nahliženo; v takovém př́padě lze uvažovat o metafoře mřrižky či filtru. Induktivní strategie oproti tomu generuje explanace (teorie), jež staví na výběru a uspořádání jevů identifikovaných v nestrukturovaném pozorování výuky. $\mathrm{V}$ této studii užíváme pojmy zavedené pro toto rozlišení Slavíkem a kol., kteří - v souvislosti s utvárením profesních soudů - hovoří o predem strukturované reflexi využívající kategorizovaná tvrzení pro výběr pozorova- ných jevů a organizaci samotného pozorování, a následně strukturované reflexi stavějící na výběru a strukturaci „pozorovaných jevů, které během výuky něčím vzbudily pozornost..." (Slavík et al., 2015, s. 15).

Dvě popsané strategie jsou $\mathrm{v}$ textu reprezentovány dvěma výzkumnými (metodologickými) př́stupy rozvíjenými $\mathrm{v}$ českém didaktickém prostoru. Jeden je $v$ textu označen jako kvantitativní videostudie (KVS) a je ilustrován postupy užívanými v konkrétním výzkumném projektu tzv. IVŠV videostudie (Janík \& Miková, 2006; Najvar et al., 2011). Druhý je označován jako obsahově zaměřený přístup (OZP) a je ilustrován obsahově zaměreným prístupem ke zkoumáni a zlepšováni výnky (Janík et al., 2013). S oporou o terminologii užívanou Slavíkem a kol. (2015 a jinde) lze říci, že KVS staví na postupech predem strukturované reflexe, zatímco OZP využívá následnè strukturovanou reflexi.

\section{DVA RŮZNÉ POHLEDY NA STEJNOU VÝUKU: KVS VERSUS OZP}

$\mathrm{V}$ dalším textu jsou představeny dvě analýzy stejného videozáznamu ${ }^{4}$ vyučovací hodiny. První analýza ilustruje výzkumnou

\footnotetext{
$\overline{2}$ Praktikami označujeme pojmenovatelný způsob jednání daný svým obsahem a kvalitou provedení, který v sobě kombinuje akty rutiny a tvorby. Zatímco rutinní složka didaktických praktik je podmínkou pro jejich typizace a kategorizace v rámci určité kultury vyučování a učení, tvůrčí složka je nezbytná pro jejich přizpůsobování aktuálním podmínkám výuky i historickému vývoji kultury vyučování a učení (Slavík et al., 2017, s. 142-147). ${ }^{3}$ Lze tu mluvit opravdu pouze o principu či tendenci; v obou přístupech jsou samozřejmě dílčím způsobem používány induktivní, deduktivní i abduktivní postupy.

${ }^{4}$ Video bývá nazýváno mikroskopem sociálních věd, čímž je míněno, že přínos videotechnologie pro rozvoj společenskovědních disciplín je srovnatelný s př́nosem, jaký měl pro rozvoj př́rodních věd vynález mikroskopu či teleskopu. Ve výzkumu realizované výuky bývá video využíváno ve snaze zachytit edukační procesy, jež jsou pro nevyzbrojené oko př́liš rychlé či př́iliš komplexní. Umožňuje také nahližet na „stejnou“ výuku z více obsahových či metodologických perspektiv, čehož dokladem je i tato studie.
} 
proceduru realizovanou v rámci projektu IVŠV videostudie 1. stupně základní školy (Najvar et al., 2011, s. 89), druhá je pohledem obsahově zaměreného přistupu využivajicího metodiku $3 A$. Právě díky tomu, že je analyzována stejná vyučovací hodina, je možné nejen vzájemně porovnat oba přístupy, ale také uvažovat o tom, jak se liší jimi generované vědění.

Vybraný videozáznam ${ }^{5}$ zachycuje vyučovací hodinu př́rodovědy realizovanou v pátém ročníku základní školy. Byl pořízen v roce 2011 v rámci $I V S ̌ V$ videostudii v úplné základní škole s cca 500 žáky, která je situována v obci $s$ více než 5000 obyvateli. Aktéry výuky byli paní učitelka $s$ více než 20 letou praxí a 28 žáků. Tato vyučovací hodina byla vybrána proto, že se v ní odehrála didakticky a kurikulárně podstatná výuková situace, k níž je smysluplné konstruovat didaktickou kazuistiku výuky v OZP; pro ilustraci KVS může tato vyučovací hodina sloužit také, stejně jako by posloužila kterákoli jiná.

\section{Předem strukturovaná \\ REFLEXE: KATEGORIÁLNÍ SYSTÉMY VYUŽÍVAJÍCÍ TEORII ČI PŘEDCHOZÍ EMPIRII (KVS)}

Pro ilustraci postupů pracujících $s$ předem strukturovanou reflexí budou níže $\mathrm{v}$ textu využity data a postupy z projektu IVŠV videostudie, který byl součástí (a může být chápán jako reprezentant) širšího proudu výzkumů využívajících videa při kvantitativních a často komparativních analýzách reálné výuky. $\mathrm{Za}$ vrchol tohoto výzkumného proudu lze považovat videostudie TIMSS realizované $\mathrm{v}$ roce 1995 (Stigler et al., 1999) a poté znovu v roce 1999 (Hiebert et al., 2003; Roth et al., 2006), jež byly zaměřeny na výuku matematiky a prírodních věd $\mathrm{v}$ osmých ročních škol v různých zemích. ${ }^{6}$

\subsection{Představení KVS}

Videostudie TIMSS vycházely z teze, že didaktické praktiky (jsouce praktikami kulturními) jsou uvnitř kultury neviditelné. Navíc jsou poznamenány návykem a stereotypem - mluví se v této souvislosti o implicitních skriptech a o pozorovatelných vzorcích chování. Proto je žádoucí zviditelňovat didaktické praktiky skrze mezinárodní srovnávání tím, že budou „v cizích kulturách“ objevovány (metodické) varianty $\mathrm{k}$ postupům, jež jsou „obvyklée v naší „kultuře“. Tyto „alternativní" postupy pak mohou přinejmenším

\footnotetext{
${ }_{5}^{5}$ Kód videozáznamu „1Pr_A2“ odkazuje k faktu, že jde o výuku na 1. stupni základní školy, výuku prírodovědy, chronologicky druhý videozáznam pořízený ve výuce učitele „A“.

${ }^{6}$ Videostudie TIMSS realizované Mezinárodní asociací pro hodnocení výsledků vzdělávání (IEA) v jistém ohledu navazovaly na dřívější behaviorálně orientované výzkumy typu proces-produkt (podrobněji srov. Janík, 2009; Starý \& Chvál, 2009). V jiném ohledu navázal tento výzkumný proud na tradici výzkumů učitelova jednání ve výuce a později pedagogické interakce (Flanders, 1970; u nás Mareš, 1981, 1988; Gavora et al., 1988). $\mathrm{Na}$ druhou stranu, na videostudie TIMSS navázaly další videostudie, částečně ve snaze kompenzovat některé jejich vnímané metodologické nedostatky (Clarke et al., 2006; Seidel, Prenzel \& Kobarg, 2005).
} 
obohatit nás didaktický repertoár, v lepším případě prohloubit učitelské porozumění výuce (Hiebert et al., 2003, s. 3-4). Jinými slovy, pohledy do jiných kultur mají sloužit jako inspirace a "protiargumenty" vůči našim vlastním kulturním (konkrétně didaktickým) praktikám, přičemž je žádoucí nahližet zejména do těch kultur, ve kterých dosahují žáci lepších vzdělávacích výsledků (pohledem souběžně probíhajících kvantitativních šetření výsledků vzdělávání TIMSS).

Prostředkem pro naplnění těchto cílů bylo ve videostudii TIMSS hledání národních vzorců výuky (country/national patterns of teaching, Givvin et al., 2005), které lze charakterizovat jako pravidelnosti ve výuce, jež jsou specifické pro jednotlivé srovnávané státy. Tyto vzorce jsou nacházeny skrze kvantitativní nahlížení na vybrané aspekty výuky ve velkém množství realizovaných vyučovacích hodin a umožňují prohloubit naše porozumění výuce. Hiebert et al. (2003, s. 4) vyzdvihují úlohu komparativních zjištění, která podle nich „mohou pomoci výzkumníkům formulovat erudované hypotézy o tom, jak které výukové praktiky ovlivňují učení. Tyto hypotézy pak mohou být východiskem pro další výzkum zaměřený na hledání toho, co je ve výuce podstatné“.

Myšlenku, že porozumění procesům vyučování a učení lze rozvíjet na základě porovnávání výuky v různých „kulturách", lze chápat obecně. Přijmeme-li tezi, že pojmem kultura lze označit souhrn didaktických praktik užívaných ve výuce určitého předmětu na konkrétním stupni školy (srov. pojem kultura vyučování a učení - Weinert, 1997, s. 12), otevíráme tím prostor pro takové způsoby budování didaktického vědění, které budou stavět na porovnávání strukturních rozdílů $\mathrm{v}$ uspořádání výuky $\mathrm{v}$ různých oborových, didaktických a systémových kontextech.

$\mathrm{V}$ českém prostředí bylo toto pojetí rozvíjeno v rámci $I V S \zeta V$ videostudii (v letech 2006-2012) při jednom z pokusů etablovat proud základniho (edukačního) vyzzkumu. ${ }^{7}$ Jejich autoři hledali způsoby, jak strukturovaně popisovat reálnou výuku na českých základních školách. K tomuto účelu sestavovali kategoriální systémy pro zachycování různých aspektů výuky (organizační formy výuky, fáze hodiny z hlediska práce s obsahem, využívání didaktických prostředků a médií apod.), s oporou o něž prováděli kvantitativní kódování základních elementů vyučovacích hodin (10sekundových intervalů). Ve spojení $s$ využíváním videozáznamů výuky umožňoval takový postup dokumentovat $s$ velkou mírou přesnosti nepřeberné množství nejrůznějších didaktických i jiných formálních charakteristik výuky.

Není bez zajímavosti, že $\mathrm{v}$ současné době se $\mathrm{v}$ režii OECD připravuje nová rozsáhlá mezinárodní videostudie ${ }^{8}$ výuky v rámci projektu TALIS (Teaching and Learning International Survey - Mezinárodní šetření o vyučování a učení).

\footnotetext{
${ }^{7}$ IVŠV videostudie byly koncipovány a realizovány jako součást projektu Centra základního výzkumu školního vzdélávání (Greger et al., 2006).

${ }^{8}$ http://www.oecd.org/edu/school/talisvideostudy.htm
} 


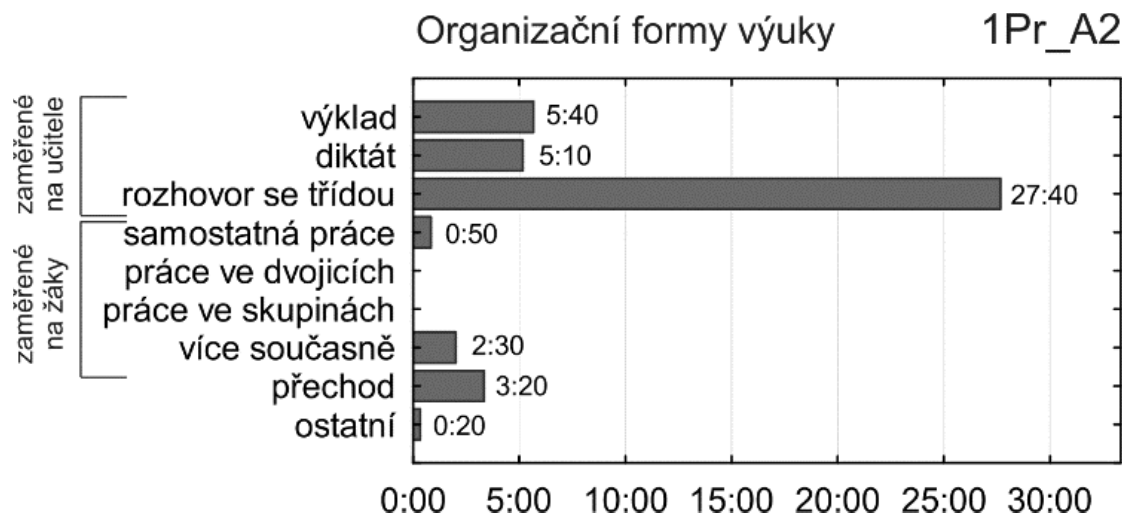

Obr.1. Organizační formy výuky zaznamenané v hodině 1Pr_A2 z hlediska výukového času

$\mathrm{S}$ oporou o videodata $\mathrm{z}$ výuky matematiky (téma kvadratické rovnice) $\mathrm{z}$ nižšího sekundárního stupně v devíti (sub)ekonomikách (včetně např́klad Spojených států, Španělska, Japonska, Anglie a Kolumbie) chtějí autoři najít odpovědi na otázky jako: „Které aspekty vyučování se vztahují (a jak) k žákovskému učení, včetně non-kognitivních výsledků učení? Jaké přístupy a prostředky jsou uplatňovány $\mathrm{k}$ výuce podobného obsahu? Jak učitelé využívají různé organizační formy pro dosažení edukačních cílů?" První výsledky mají být $\mathrm{k}$ dispozici v roce 2019 a pořízené videozáznamy mají být základem globálni on-line videobanky výukových praktik.

\subsection{Př́íklad k osvětlení KVS}

Vezměme za př́iklad výše představený videozáznam výuky prírodovědy v 5 . ročníku a ilustrujme, jaké poznatky o konkrétní vyučovací hodině lze $s$ oporou o predem strukturujicí kategoriální systémy formulovat. (V této vyučovací hodině bylo kódováno 270 desetisekundových intervalů mezi explicitním učitelčiným zahájením výuky a jejím ukončením.) Pro zachycení toho, jak je výuka organizována z hlediska interakce a komunikace mezi učitelem a žáky a mezi žáky navzájem, byl využíván kategoriální systém Seidelové, Prenzela, Kobargové et al. (2005), jež byl později adaptován Janíkem a Mikovou (2006). Ve zkoumané hodině (obr. 1) z tohoto hlediska výrazně převládal rozhovor učitele se tř́idou, který probíhal téměr 28 minut. (Monologický) výklad učitele a diktát byly výrazně méně zastoupeny; ve výuce téměř neprobíhala samostatná či skupinová práce žáků.

Díky tomu, že je zkoumán videozáznam výuky, je možné opakované iterativní a rekurzivní zkoumání stejné výuky (pro diskusi specifických výhod využivání videa ve výzkumu výuky srov. Najvar et al., 


\section{Pr_A2}
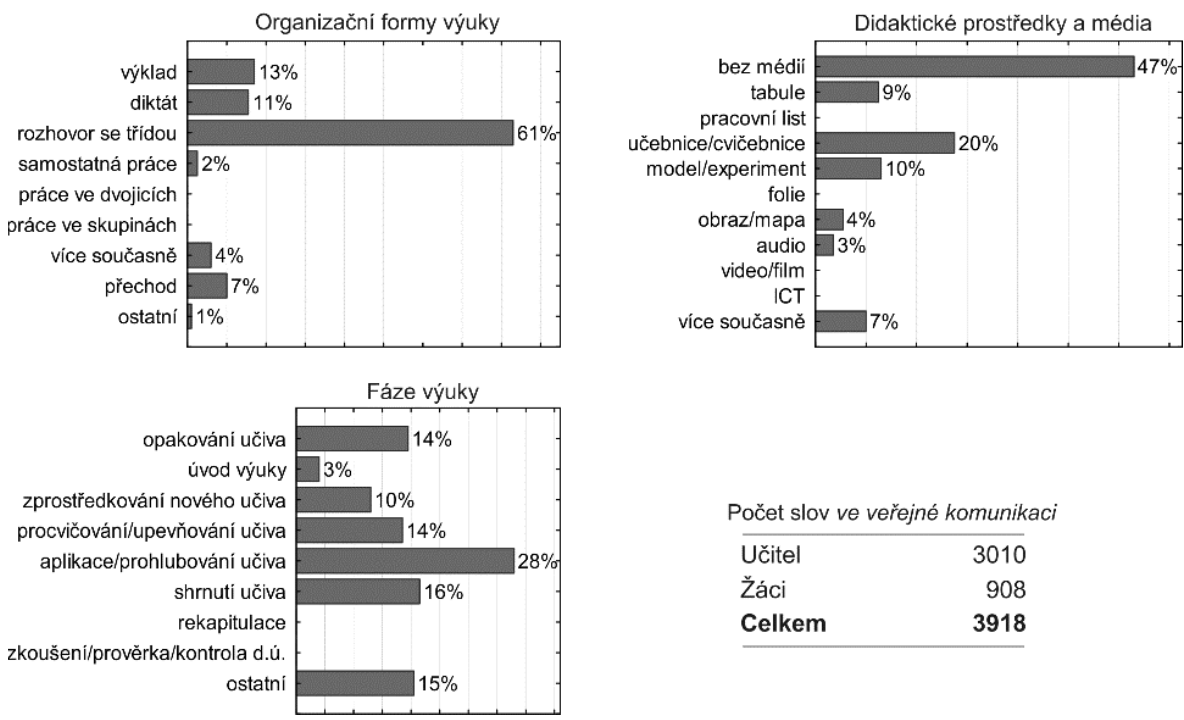

\begin{tabular}{lr} 
Počet slov ve veřejné komunikaci \\
\hline Učitel & 3010 \\
Žáci & 908 \\
Celkem & 3918
\end{tabular}

Obr. 2. Komplexní pohled na zkoumanou hodinu (juxtapozice vybraných aspektů)

2011, s. 31-36). Na jednu stranu tedy lze propojovat jednotlivé dílčí vhledy na izolované aspekty, tzn. kupř́kladu nabídnout zároveň pohled na organizačni formy výuky, fáze hodiny z hlediska práce s obsahem a didaktické prostredky a média (obr. 2) a umožnit tak komplexní a relační pohled na zkoumanou výuku. ${ }^{9} \mathrm{Na}$ druhou stranu lze každý analyzovaný desetisekundový interval umísit na časovou osu, a tím zachytit časovou (procesuální) dimenzi zkoumaného aspektu výuky (obr. 3). Popsaný postup vede $\mathrm{k}$ vytvoření záznamu (tzv. otisku, angl. lesson signature) jedné vyučovací hodiny.
Př́nos KVS pak spočivá ve strukturovaném náhledu na větši množství vyučovacích hodin; teprve toto prekládáni či navrstveni „otiskü“ jednotlivých hodin (obr. 4) může napomoci hledání pravidelností či vzorců ve výuce, at už charakteristických pro výuku v konkrétní národni kultuře, v některém vyučovacím predmètu, v určité skupinè učitelů apod.

Popsaný proces vrstvení dává vzniknout otisku jakési priomèrné hodiny za určitý základní soubor (soubor hodin realizovaných konkrétním učitelem či $\mathrm{v}$ určitém školním předmětu či v určitém geografickému regionu apod.). Tento otisk zachycuje průměrné

${ }^{9}$ Pozoruhodné poznatky o této konkrétní vyučovací hodině přinášejí i Češková a Knecht (2016) či Pospíšilová (2012). 


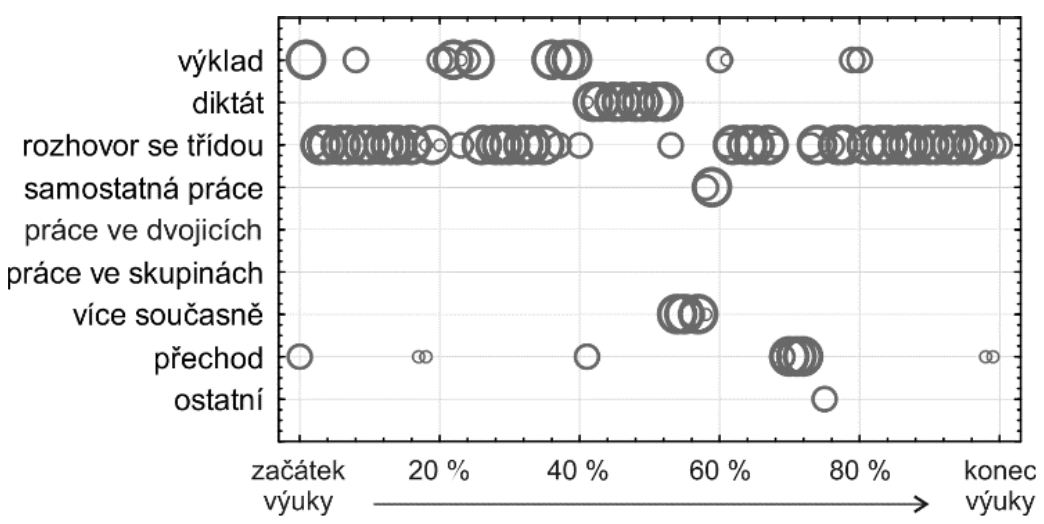

Obr. 3. Organizační formy výuky zachycené na časové ose vyučovací hodiny $1 \mathrm{Pr} \_\mathrm{A} 2$

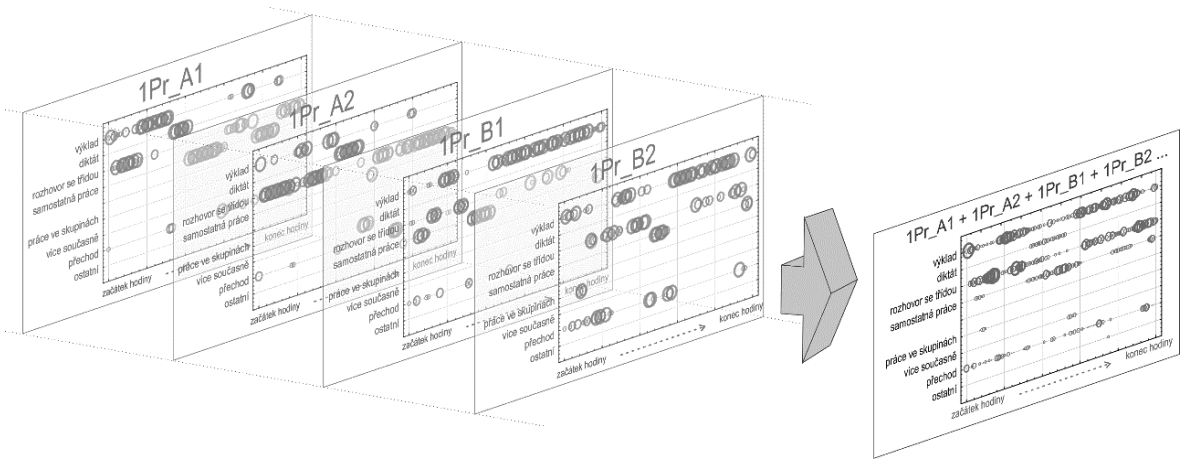

Obr. 4. Hledání pravidelností „vrstvením“ otisků vyučovacích hodin

zastoupení jednotlivých kategorií kategoriálního systému, resp. „zprůměrovaný“ průběh vyučovací hodiny (Najvar et al., 2011, s. 124). Je to také postup, který umožňuje objevovat pravidelnosti v didaktických praktikách, vyhledávat a vymezovat (proto)typy učitelů či vyučovacích hodin ${ }^{10}$ a zkoumat dále jejich charakteristiky. ${ }^{11}$ Zde je potřeba prripome-

\footnotetext{
${ }^{10}$ Např. Hugenerová et al. (2008) analýzou 39 vyučovacích hodin matematiky (zaměřených na učivo o Pythagorově větě) realizovaných v Německu a Švýcarsku identifikovali pomocí KVS tři vyučovací vzorce: výkladový, problémově-rozvíjející a problémově-objevující.

${ }^{11}$ Nap̌r. Seidelová a Prenzel (2006) zkoumali stabilitu výukových vzorců učitelů fyziky ve výuce různých témat; objevili varianty/variace v oblasti organizace aktivit, ale určitou míru stability (invariantnosti) v modech interakce učitele a žáků a v tom, jak studenti vnímají podpůrné učební podmínky ve výuce.
} 


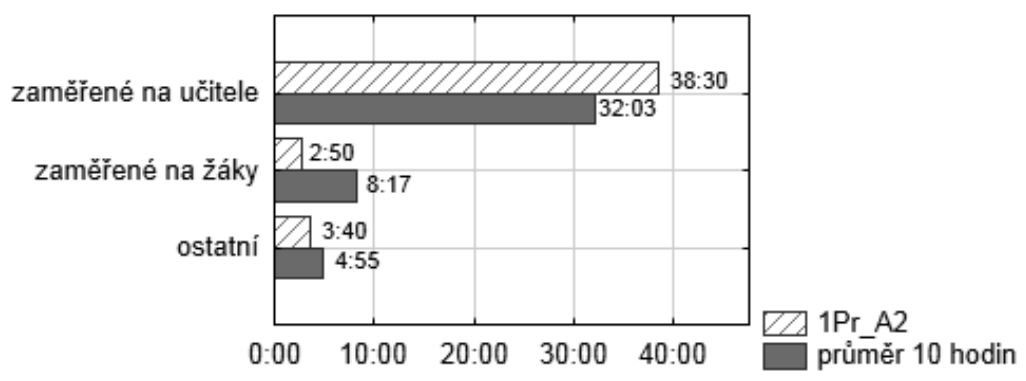

Obr. 5. Porovnání hodiny $1 \mathrm{Pr} \_A 2 \mathrm{~s}$ „průměrnou hodinou“ přírodovědy

nout, že tyto poznatky jsou deskriptivní povahy, tj. charakterizují zkoumanou výuku, ale nepřekračují výše zmíněnou „mezeru“ směrem k hodnocení její kvality.

Pokud jde o zkoumanou hodinu prrírodovědy, organizační formy výuky ${ }^{12}$ (sloučené do širších kategorií forem zaměrených na učitele, tj. výklad, diktát, rozhovor se třídou, a zaměrených na žáky, tj. samostatná práce, práce ve skupinách) lze porovnávat $s$ „průměrnou hodinou“, tj. otiskem celého vzorku 10 hodin přírodovědy v pátém ročníku (obr. 5). Takové srovnání může ukázat, že oproti ostatním hodinám bylo ve zkoumané hodině více výukového času věnováno formám, ve kterých ležela zodpovědnost za obsah, tempo či dynamiku interakcí na učiteli - formy zaměrené na učitele.

\subsection{Potenciál KVS}

Možnosti podobného srovnávání určité vyučovací hodiny či sady hodin s jinými hodinami či sadami hodin jsou v principu neomezené. Jsou-li k dispozici velké počty videozáznamů hodin vybraných tak, aby mohly být zdůvodněně považovány za reprezentativní pro určitou kulturu vyučování a učení v určitém oboru školního vzdělávání, potom lze navrhovat a pomocí statistických procedur ověřovat hypotézy o vztazích mezi pozorovanými charakteristikami výuky. Je také možné ověřovat, do jaké míry odpovídá výuka a priori formulovaným doporučením (např. využívat určité formy výuky, didaktické prostředky, metodické postupy).

Jsou-li $\mathrm{k}$ dispozici data o vzdělávacích výsledcích žáků zachycených na videozáznamech, potom lze formulovat a ověrovat hypotézy o vztahu pozorovaných fenoménů (např. vzorců výuky) a lepších či horších výsledků žáků, tj. v důsledku identifikovat ty postupy, které vedou k nejlepším výsledkům (tj. hlubším či trvalejším znalostem, účelnějším dovednostem, společensky přijatelnějším postojům, rozvinutějším kompetencím apod.). $\mathrm{V}$ takovém prrípadě je výše

${ }^{12}$ Konkrétní pojetí organizačních forem výuky je inspirováno výzkumem Seidelové et al. (2005). 
uvedená „mezera“ mezi popisem pozorovaných vlastností výuky a jejich hodnocením přemostěna korelací dvou datových souborů: jeden popisuje vlastnosti výuky a druhý hodnotí výkon žáků, kteří se výuky účastnili. Korelace je potom východiskem a ospravedlněním hodnocení: jsou-li výkony žáků, kteř́i „prošli“ touto výukou, lepší než výkon žákủ, kteř́i „prošli“ výukou jinou, pak lze první výuku pokládat za kvalitnější.

\subsection{Limity KVS}

Představa, že KVS umožní jednoduché roztřídění výukových postupů na efektivní a neefektivní, a tím pomůže formulovat univerzální metodická doporučení pro učitele, však neobstojí. Vystihují to Šedová a Šalamounová (2016, s. 66), když s poukazem na práci Lefsteina a Snellové (2014) uvádějí: „... metoda, která funguje $\mathrm{v}$ jednom kontextu, nemusí stejně fungovat $\mathrm{v}$ jiném, a proto naučit se pracovat $s$ novou vyučovací metodou znamená víc než imitovat její povrchovou strukturu, vyžaduje to citlivou schopnost posoudit možnosti jejího produktivního využití". Toto varování poukazuje na situační jedinečnost: ani v jedné škole nejsou dvě třídy stejného ročníku zcela shodné a kvalitní výuka vykazuje známky citlivého přizpůsobení metod každému jednotlivému př́padu. A to platí $\mathrm{i} v$ širších - kurikulárních - souvislostech. Také Stigler a Hiebert (1998) jako jedni z duchovních otců videostudie TIMSS poukazují na fakt, že výukové praktiky je třeba vnímat jako součásti širších kulturních skriptů, nikoli jako dílčí aktivity, jež lze snadno izolovat a implementovat do výuky uvnitř jiné „kultury“.
Jiný problém, který může být chápán jako limitace prístupu KVS, se vyjeví v souvislosti $s$ otázkou, do jaké míry vůbec lze porovnávat jakékoli dvě různé vyučovací hodiny s oporou o kategorizaci jejich vlastností. Pokud každé setkání konkrétního učitele (s jeho osobnostními a profesními dispozicemi a historií) s konkrétními žáky (s jejich individuálním předvěděním a skupinovou dynamikou) nad konkrétním učivem (vybraným vzdělávacím obsahem $\mathrm{v}$ autentické realizaci) za unikátních podmínek pojímáme jako jedinečnou intersubjektivní strukturaci obsahu v učebním prostředí, jedná se vždy o novou, neopakovatelnou situaci. Srovnávat vyučovací hodiny (notabene desítky či stovky vyučovacích hodin) z hlediska kvality je pak stejně problematické jako hodnotově srovnávat dvě umělecká díla $\mathrm{z}$ různých období (srov. pojem pedagogické dílo - Slavík, 1996). KVS na tento problém reagují tak, že zaostřují pozornost na to, co lze např́ć vyučovacími hodinami považovat za konstantní či společné, tj. vlastnosti procesu utváření a transformování obsahu (sem spadá i metodický postup při práci s obsahem). Vyhýbají se tím však náhledu na to, jak se ve výuce utvárí a transformuje obsah samotný.

\section{NÁSLEDNĚ STRUKTUROVANÁ REFLEXE: OBSAHOVĚ ZAMĚŘENÝ PŘÍSTUP V METODICE 3A}

Aby mohl být výše uvedený rozdíl mezi KVS a OZP lépe osvětlen, je v následující části textu představen jiný proud ve zkoumání výuky, označovaný jako obsahově zaměřený přístup (OZP), který 
odpovědi na některé $\mathrm{z}$ naznačených výzev pojímá diametrálně odlišně, což umožňuje nahlédnout na oba proudy kontrastivně a poukázat tím na některé jejich silné stránky a limitace při zkoumání (kvality) výuky.

\subsection{Představení OZP}

Obsahově zaměřený prrístup byl vyvinut částečně v reakci na výše prezentovaný proud výzkumů zaměřených na kvantitativní aspekty výuky. Reaguje na potřebu nepouštět ze zřetele to, co poskytuje vzdělávací smysl učebním úlohám a čemu se žáci učí, tj. obsah učení a vyučování. ${ }^{13}$ Jedná se o hledisko, které ve výuce běžně zaujímá učitel, když se snaží svým žákům obsah co nejlépe přibližit nebo když jim pomáhá překonávat překážky v učení. Ze zahraničních přístupů je blízký např́íklad německé tradici didaktiky „Didaktik“, jež zdůrazňuje, že výzkum se má vedle učitele a žáka zaměřovat na to, jakým zpuisobem je obsah reprezentován ve výuce, nebot' „předepsaný obsah se stává vzdělávacím obsahem teprve tehdy, když je interpretován a realizován učiteli“" (Willbergh, 2011, s. 158). Ohled na obsah $s$ přesahem do prípravy učitelů je mimo to charakteristický např́klad pro metodiku klícových didaktických událostí (critical didactic incidents - CDI) ${ }^{14}$.

Za klíčový lze považovat fakt, že obsah je chápán a vykládán ve dvojím kontextu:
1. v kontextu kurikula s ohledem na př́slušné obory - tj. $\mathrm{z}$ ontodidaktického hlediska, a 2. v kontextu žákovských činností v reálné výuce - tj. z hlediska psychodidaktického. Nejde tedy jen o analýzu elementů a vazeb v kurikulu, která by pomíjela žákovské učení, ale ani jen o formální analýzu činností a interakcí učitele a žáků. Obsahově zaměrený prýstup má tak ambici nabídnout analytický pohled na setkáni učitele a žáků $s$ určitým obsahem a tedy výsekem kurikula, který je označen za (ontodidakticky) klíčový či (psychodidakticky) kritický.

Vnitřní validity je v OZP dosahováno porovnáváním (dvou) různých hodnotových alternativ metodických postupů pro tentýž obsah (výukovou situaci) - původní analyzované situace a její tzv. alterace. Tento princip sdílejí i jiné výzkumné přístupy zaměřené na obsahovou stránku zkoumání kvality výuky. Např. podle Labordeové (1997) sestává vnitřní validace „z porovnávání dvou různých modelů téhož objektu (výukové situace), kterými jsou a priori analýza a a posteriori analýza" (citováno $\mathrm{z}$ angl. dle Buty, Tiberghien \& Le Marechal, 2004, s. 581).

Nástrojem pro zkoumání a reflektování výukové situace je $\mathrm{v}$ obsahově zaměřeném př́stupu didaktická kazuistika, která umožňuje „do potřebné hloubky studovat a teoreticky objasňovat procesy didaktické transformace obsahu" (Slavík et al., 2017, s. 10). Jde o explicitní odkaz

\footnotetext{
$\overline{{ }^{13} \text { Jak s oporou o Gruschku (2013) apelují Slavík et al. (2017, s. 185), ve výzkumu vzdělávání je třeba se více }}$ „zaměřovat na to, zda a jak cesty (dorozumívání) vedou k porozumění. Předpokládá to realizovat výzkumy procesů vedoucích k porozumění, nestačí pouze snímat stav znalostí a kompetencí.

${ }^{14}$ Více o vztahu metodiky klíčových didaktických událostí a obsahově zaměřeného přístupu pojednávají Slavík et al. (2017, s. 281-288).
} 
na Shulmanovy teze o roli prrípadových studií (nejen) ve výzkumu uplatňování didaktických znalostí obsahu (Shulman, 1996; Brandt, 1992). Jádrem kazuistiky je tzv. konceptová analýza výukové situace, která $\mathrm{k}$ zachycení obsahových jader výukové situace a vztahů mezi nimi využíá model hloubkové struktury výuky. Ten respektuje klíčové determinanty výuky: vzdělávací obsah, vzdělávací cíle a žákovské zkušenosti a činnosti ve výuce.

Pro standardizaci postupu vytvárení kazuistiky byla vyvinuta tzv. metodika 3A (Janík et al., 2013, s. 217-256; původně i metodika AAA), jejíz název odkazuje $\mathrm{k}$ faktu, že kazuistiky jsou strukturovány do tří částí: anotace, analýzy a alterace. ${ }^{15}$ $\mathrm{V}$ anotaci jsou představeny kurikulární a didaktické souvislosti analyzované výukové situace. $\mathrm{V}$ analýze je pomocí standardizovaného konceptového diagramu ${ }^{16}$ zachycen mentální pohyb žáků (učení) $\mathrm{v}$ prostoru mezi světem jejich přirozené zkušenosti a světem oboru. Z hlediska kultivování profesního myšlení a profesního jazyka je podstatné, že kazuistika ústí právě do návrhu alterace - tj. alternativního postupu při zachování celkového tvaru výukové situace - a její reflexe a diskuse.

\subsection{Příklad k osvětlení OZP}

Následující cást textu je komentovaným náhledem na strukturu didaktické kazuistiky konstruované metodikou 3A. Jednotlivé strukturní prvky kazuistiky jsou velmi stručně představeny a modelově popsány na př́kladu didaktické kazuistiky s názvem „Rybník“. Tato kazuistika se týká výukové situace zachycené na videozáznamu 1Pr_A2 (v čase 32:00-43:30), tj. ve vyučovací hodině analyzované výše (viz Př́klad k osvětlení KVS).

Běžným písmem je uváděn komentár ke struktuře kazuistiky, proloženým písmem ukázka textu kazuistiky.

\section{ÚvoD}

Zkoumaná výuková situace se odehrála v poslední třetině vyučovací hodiny a jejím tématem byla ochrana životního prostředí. Nejprve zde pro ilustraci vybíráme úvodní část kazuistiky. $\mathrm{V}$ metodice $3 \mathrm{~A}$ má být tato část věnována stručnému objasnění hodnoty či podnětnosti tématu kazuistiky - tím má být předběžně zdůvodněn výběr těch situací výuky, které jsou předmětem analýzy. Pozornost je zaměřna na didaktické

\footnotetext{
$\overline{{ }^{15} \text { Autory kazuistik bývají zpravidla oboroví didaktici, kteří (v jisté paralele k lingvistické či uměnovědné analý- }}$ ze) hledají (sémanticko-logickou) strukturu ve výsledném tvaru (pedagogického) díla. Nezřídka však na tvorbě kazuistiky spolupracuje oborový didaktik $s$ učitelem, který vedl analyzovanou výuku; v takovém př́padě jde o situaci podobnou setkání lékařského konzilia hledajícího porozumění závažnému př́ípadu. Ve srovnání $s$ tím v KVS je výzkumník v roli karteziánského zkoumajícího subjektu.

${ }^{16}$ Konceptový diagram zachycuje sémanticko-logickou strukturu výukové situace, která je „relativně nejstabilnějším vzdělávacím a matematizačním jádrem obsahu ve výuce“ (Slavík et al., 2017, s. 317). K tomu využívá tři vrstvy: tematickou (která zachycuje přrirozenou zkušenost žáků), konceptovou (zachycující pojmovou sít oborového obsahu určeného $\mathrm{k}$ učení) a kompetenční (která poukazuje na směřování $\mathrm{k}$ nadoborovým cílům). Pokud analýza ukáže problém v souladu těchto tří vrstev, usuzuje se na problém v integritě výuky a na problém tzv. didaktického formalismu.
} 
uchopení určitého klícového či kritického obsahu z hlediska kurikula př́slušného/odpovídajícího oboru.

$V$ pozorované hodině prírodovédy - presesnèji ve výnkové situaci $v$ závèru vyučovací hodiny - lze za didakticky podnétné považovat setkáni oborového obsahu ochrany životního prostredi v rámci studovaného biotopu (rybnik) se zkušeností žákù s neukáznèným chovánim v prírodè (odhazováni odpadkư). Kurikulárnè je téma dũležité $i$ tím, že vedle potřebného znalostniho fundamentu nese silný náboj afektivní a etický. Varianty environmentálni výchovy jsou i proto soucáatí rüzných modernich reformnich snah (srov. naprr. globálni výchova - Horká, 2000, s. 29). Nad vybranou výukovou situaci je tedy konstruována didaktická kazuistika s názvem „Rybnik aneb Jak propojovat vzdèlávací a výchovné cile ve výuce prírodovédy".

\section{Anotace}

Anotace pomáhá čtenáŕi porozumět zasazení zkoumané výukové situace do širšího celku výuky. Vnitřně je dále strukturována do dvou částí:

1. kontext výukové situace,

2. didaktické uchopení obsahu.

Kontext výukové situace - cíl, téma, návaznost obsahu

První část anotace představuje cílové zaměření zkoumané výukové situace a strukturu pojmů, která obsahově vymezuje rámec pro činnosti žákủ. Jde v ní o zachycení kurikulárního kontextu, tj. návazností v projektované a realizované dimenzi kurikula. Ilustrují to následující dva odstavce kazuistiky. Z obou je dobře patrné soustředění na problematiku vzdělávacího obsahu v kurikulu a ve výuce:

$Z$ hlediska oborů (které sytí konceptovou vrstvu konceptového diagramu) leži téma na pomezi biologie a ekologie. Zkoumaná výuková situace se kurikulárnè vztahuje $k$ vzdèlávaci oblasti Člověk a jeho svèt, konkrétně $k$ tematickému okruhu Rozmanitost prírody, a zde $k$ očekávanému výstupu ve 2. obdobi: „žák zhodnoti některé konkrétni cinnosti clověka v prírodè a rozlišuje aktivity, které mohou prostředí i zdravi clověka podporovat, nebo poškozovat". Naplňováni tohoto výstupu je dosahováno skrze učivo „ohleduplné chováni k prírodě a ochrana prírody - odpovédnost lidi, ochrana a tvorba životniho prostredí, ochrana rostlin a živočichü, likvidace odpadì, živelni pohromy a ekologické katastrofy" (RVP $Z V, 2016$, s. 48). Podle očekávaného výstupu formulovaného ve školnim vzdèlávacím programu školy žák na konci 2. obdobi "chová se podle zásad ochrany prírody a životního prostredi" a "popisuje vliv činnosti lidi na prírodu a jmenuje některé činnosti, které prírodnimu prostredi pomáhaji a které ho poškozuji".

Výuková situace byla zar̆azena do kontextu výkladu k pojmu ryby. Žáci se v predcházejicich hodinách vènovali tématu savci (charakteristika skupiny a podrobněji zástupci - srnec obecný, krtek obecný), ptáci (charakteristika skupiny a podrobnèji zástupci - vlaštovka obecná, bažant obecný, kachna divoká) a nyní navazuji tématem ryby. Pojem rybnik byl vyvozen jako prirozený biotop pro dva predstavované zástupce této skupiny (kapr obecný, stika obecná). V prèdcházejicí hodinè diskutovala pani učitelka se žáky o aktuálni havárii elektrárny Fukušima a jejim dopadu na životni prostředi (ryby v moři), v aktuálni hodiněje 
diskuse vedena od obecných charakteristik ryb právě $k$ potřebè ochrany životniho prostředina príkladu biotopu rybnik.

\section{Didaktické uchopení obsahu - činnosti učitele a žáků}

Druhá část anotace má především zachytit kotext výukové situace jako souhrn toho, co lze ve výuce bezprostředně pozorovat (Slavík et al., 2017, s. 199). Důležitou součástí je i popis jádrové činnosti, ve které se „propojuje zkušenost žáků s př́ílušným oborem“ (Janík et al., 2013, s. 225). Soustředění na jádrovou činnost je klíčové, protože žáci mohou do hloubky porozumět obsahu pouze tehdy, mohou-li při učení př́hodně navázat na vlastní dosavadní zkušenost a znalosti:

Výuková situace se odehrála "na koberci“ $v$ zadni části trídy; na jejím počátku si žáci sedli do velkého kruhu, který mél symbolizovat okraj rybnika. Jeji proni cást byla motivačni; znělo CD s relaxačnimi zvuky zpěvu ptákì a šumění vln a žáci si méli se zavrenýma očima vyvolávat libou prédstavu okouzlujici prírodni scenerie na břehu rybnika. "Př́jemná" situace byla nenadále ukončena tím, že pani učitelka v prevleku za "nevychovaného kluka" vhodila doprostřed "rybnika" několik predmètů: sklenici, mikrotenový sáček, plastovou láhev a papirovou krabici. V následujicim rozhovoru (transkript niže) vedla žáky k reflexi prožitku z hlediska miry ekologické zátěže, kterou jednotlivé materiály, z nichž jsou odpadky vyrobeny, pro daný biotop predstavuji.

Dle komentáre učitelky je výuková situace inspirována absolvovaným metodickým seminárem pro učitele a pravidelně každý rok realizována šzáky pátých ročniku.
${ }_{i r}$ U: Príhlásíme se. Co se tady stalo? Décka, kdo jste co vidèli, prosim vás.

${ }_{i 2} Z$ : Někdo semka házel odpadky.

is U: Někdo semka hodil ... co to je?

${ }_{i 4} Z$ : Sklinky.

${ }_{i 5} Z$ : Odpad.

${ }_{6} U:$ Co to je?

Z: Fuj.

Z: Odpad.

${ }_{\text {ig }}$ U: To byl nèjakej kluk určitě a prì̌el semka vysypat néjakej odpad. Já se do toho rybnika podivám, co to je?

${ }_{i 10} Z:$ Obal.

${ }_{\text {rll }} U$ : Dècka a ted'se vás zeptám. Podivejte se, najednou nám to plave po rybniku, v rybnice to je, co myslite, $z$ čeho to je? Priblásime se. Katko.

Z: Z papiru.

${ }_{3} U: Z$ papiru. A myslite si, za jak dlouho se rozloži papir ve vodé.

${ }_{i 14} Z: Z a$ pèt dní.

${ }_{\text {¿15 }} Z: Z$ : Za chvilku.

U: Za pét dni, to je brzo.

${ }_{17} Z: Z a$ pèt minut.

${ }_{8} U:$ To je ještě driv.

${ }_{i 19} Z: Z a$ deset dnu.

${ }_{20} Z: Z a$ týden.

${ }_{121} Z: N i k d y$.

U: Za několik týdnů určitě, takžes papirem dokáže se rybnik, voda vyrovnat? Jakžtakž jo. Co se nám tady objevilo?

${ }_{i 23}$ ZZ: Sklo.

${ }_{24}$ U: Sklo. Jak dlouho tam bude, v tom rybnice, dècka, co myslite?

${ }_{i 25}$ Z: Hodné dlouho.

Z: Aspoň navždy.

${ }_{27} Z$ : Napoŕád.

${ }_{28} U$ : Myslite si, že se sklo rozloží nějak samo? ${ }_{29} \mathrm{Z}: \mathrm{Ne}$. 
${ }_{r 30} Z:$ Ano.

${ }_{331} U$ : Tomás mysli ano, kdo si mysli, že ne, zvedne ruku.

${ }_{i 32} Z$ : Já.

${ }_{{ }_{33} 3} U:$ Kolik rukou nahoře? Sklo tam bude, sklo tam zuistane. Sklo tam zuistane. A co to tady máme, co to je?

${ }_{r 34} Z$ : Sáček.

${ }_{335} U:$ Sáček. Z čeho je sáček?

${ }_{i 36} Z: Z$ plastu.

U: Décka, vite něco o plastech? Jak dlouho tam zưstanou plasty?

Z: Pani učitelko, mamka ríkala, že když sáček takovej zakopete pod zem, tak vydrži klidně 50 let.

${ }_{339} U$ : Určitě má maminka pravdu, a možná $i$ dýl. Určitě $i$ dýl. Čili, co mnè reknete o tom rybniku? Dokáže se vyrovnat rybnik s takovým igelitovým sáčkem?

${ }_{r 40} Z Z: N e$.

${ }_{\check{r} 41} U:$ Nedokáže.

\section{Analýza}

Strukturace obsahu - rozbor s využitím konceptového diagramu

Konceptový diagram zachycuje základní strukturaci obsahu ve výuce. Odráží logickou strukturu nejdůležitějších obsahových prvků a zachycuje „významovou kostru“ tvorby učebního prostředí. Konceptový diagram tyto obsahové prvky uspořádá do tří vrstev: tematické, konceptové a kompetenční (cílové). Vrstvy reprezentují hlavní didaktické stránky či dimenze výuky. Tematická vrstva konceptového diagramu dokumentuje tu stránku výuky, která má respektovat žákovský přístup k obsahu. Jejím úkolem je tematizovat objekty a jejich vlastnosti, které jsou nejblíže žákovské zkušenosti a znalos- tem. Tím naznačuje, jak asi primárně hodinu vidí žák (potažmo jakýkoli laik). Konceptová vrstva zachycuje základní významovou a logickou strukturu učiva, zjednodušeně: vzdělávací obsah transformovaný $\mathrm{z}$ oborů (z kultury) a nabízený žákovi $k$ osvojení. Kompetenční vrstva ukazuje a strukturuje cíle, jež jsou integrující, nadoborové povahy. Izolování těchto tří vrstev pomáhá rozlišit a navzájem propojit tři perspektivy, které jsou klíčové pro porozumění „obsahovosti“ učení. Teprve jejich rozlišení totiž umožňuje náhled na to, jak (dobře) jsou provázány, tj. na integritu výuky (Slavík et al., 2017, s. 341), která je chápána jako „ústřední strukturní determinanta kvality učebního prostředi“" (tamtéž, s. 306). Integrita výuky je rozhodující pro kvalitu výukové situace jako příležitosti k učení, nebot čím vyšší je integrita, tím menší je rozvolnění vztahů mezi cíli, obsahem a zkušeností žáků. Právě toto rozvolnění zakládá didaktický problém označovaný v obsahově zaměřeném prístupu jako didaktický formalismus (tamtéž, s. 312).

Konceptový diagram analyzované výukové situace (obr. 6) zachycuje v tematické vrstvě kontextový pojem rybník, a dále hyperonymum odpadky a $k$ němu hyponyma krabička, sáček, sklenička, láhev, tj. pojmy, ježžáci vstupujici do výukové situace běžnè uživaji; a vedle toho ještě autentické výrazy rozloží se a vydrží jako vlastnosti jednotlivých predmètü. Konceptová vrstva zachycuje pojmy, které jsou k pojmưm tematické vrstvy v jistém smyslu "protèjšky“, nebot pojmenovávají jejich klicový atribut z hlediska ekologické zátěže, tj. materiál, ze kterého jsou príslušné reálné predmèty vyrobeny (papír, plast, sklo); a vedle toho pojmy vlastnost materiálu a doba rozpadu. Rámujicimi pojmy konceptové vrstvy jsou životní prostředí 


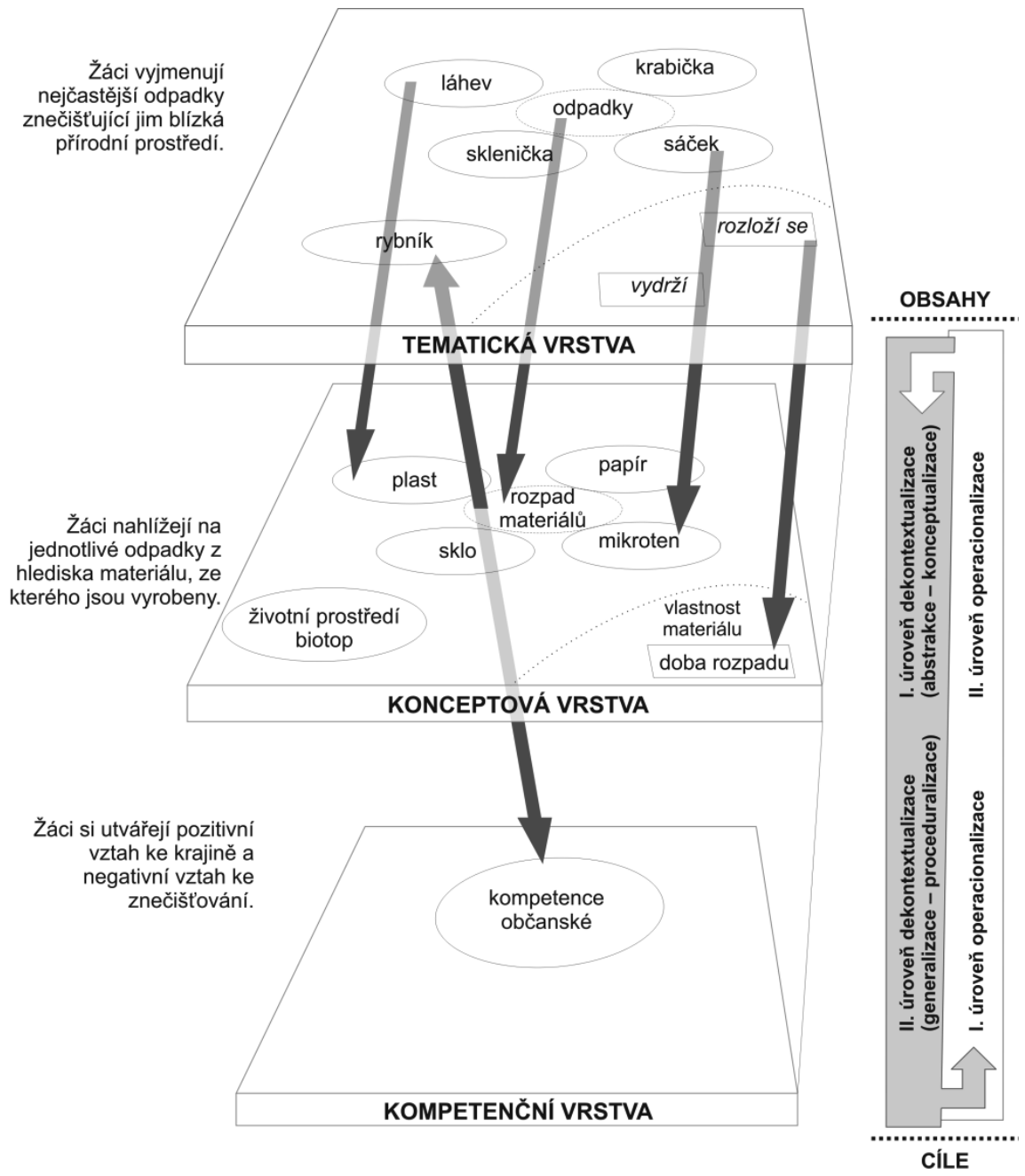

Obr. 6. Konceptový diagram výukové situace „rybník“

a specificky biotop. Kompetenčni vrstva ukazuje, že výuková situace sméruje k rozvijeni kompetence občanské, která zahrnuje to, že žák, ,chápe základni ekologické souvislosti a environmentálni pro- blémy, respektuje požadavky na kvalitni životni prostředi, rozhoduje se v zájmu podpory a ochrany zdravi a trvale udržitelného rozvoje společnosti" (RVPZV, 2016, s. 12). 
Rozbor transformace obsahu s výhledem $k$ alteraci

Druhá část analýzy se zaměruje na kvalitu propojení jednotlivých vrstev konceptového diagramu, tj. na potenciál situace $\mathrm{k}$ podpoře učení žáků (které se odehrává $\mathrm{v}$ pohybu mezi tematickou a konceptovou vrstvou konceptového diagramu), př́padně na vztah oborových a nadoborových cílů (dokumentovaných na konceptové, resp. kompetenční vrstvě). Pro ilustraci tohoto postupu opět využiváme ukázku z kazuistiky:

Analyzovaná výuková situace predstavovala príležitost $k$ tomu, aby žáci nahlédli „za“ reálné predmèty, které znaji jako "odpadky“ (o), a na materiál, z něhož jsou vyrobeny ( $m$ ), $z$ hlediska jeho "rozložitelnosti" $v$ biotopu "rybnik jako kličové charakteristiky (ch)“. Tabulka 1 ukazuje razeni pojmù v prüběhu rozhovoru učitelky se trídou s poukazem na chybèjici mista.
Potenciál výukové situace byl do jisté míry využit. Pozornost žákủ byla privedena $k$ obalovým materiáluim, které se stávaji odpadky, čimž byly zexplicitnèny některé procesy, které žáci implicitně ze své zkušenosti znaji. Byl problematizován zpiosob, jakým se príroda (reprezentovaná konkrétnim biotopem) tèchto materiálì „zbavuje“. K jednotlivým materiáli̊m byl prirazazen časový údaj pro odbouráváni, podle kterého je možné kvantiflkovat míru zátěže, jakou daný materiál predstavuje pro životni prostředí.

\section{Alterace}

Alterace je třetím krokem metodiky 3A. Završuje analýzu výukové situace návrhem hypotetické zmèny $\mathrm{v}$ myšlenkovém obrazu výuky a sledováním, zdali lze tuto (myšlenou) změnu zdůvodněně označit za „zlepšující". Zároveň ale sama slouží jako zpětná kontrola pro předcházející analýzu: návrh

Tab. 1. Rozbor řazení pojmů ve výukové situaci

\begin{tabular}{|c|c|c|}
\hline Řádek & Citace & Komentár \\
\hline rq & odpad & Ucitelka indukuje obecný zastřešujici pojem. \\
\hline rq & Já se do toho rybnika podivám. & Ucitelka iniciuje analytický pohled do centrálni kategorie. \\
\hline- & krabice & (Chybi zavedeni pojmu krabice (o1) pro typ odpadku.) \\
\hline$\check{r} 11$ & $Z$ čeho to je? & Poprvé je užita otázka na vztah mezi (o) a (m). \\
\hline ŕ13 & papir & Zaveden pojem pro materiál $(\mathrm{m} 1)$ \\
\hline r22 & několik týdnů & Kličová charakteristika (ch1). \\
\hline- & sktenice & (Chybi zavedeni pojmu sklenice (o2) pro typ odpadku.) \\
\hline$r 24$ & sklo & Zaveden pojem pro materiál $(\mathrm{m} 2)$ \\
\hline r33 & Ziistane tam. & Klićová charakteristika skla (ch2). \\
\hline$r 34$ & sáček & Zaveden pojem pro typ odpadku (o3). \\
\hline$\check{r} 35$ & Z čeho je sáček? & Podruhé je užita otázka na vztah mezi (o) a (m). \\
\hline$r 36$ & plast & Zaveden pojem pro materiál (m3). \\
\hline$\check{r} 41$ & nedokáže se vyrovnat & Kličová charakteristika (ch3). \\
\hline
\end{tabular}

Pozn.: o1,2,3 - objektlodpadek; m1,2,3 - materiál; ch1,2,3 - charakteristika 
alterace totiž obvykle nabídne nový způsob uvažování o výuce a pomáhá analýzu prohloubit a upřesňovat (srov. Rusek, Slavík \& Najvar, 2016, s. 85-87). Naplňují se tím dvě ambice metodiky 3A: hodnotit kvalitu analyzované výukové situace $\mathrm{z}$ hlediska toho, jakou vytvárí príležitost pro učení žáků konkrétnímu oborovému obsahu (a rozvoji konkrétních nadoborových kompetencí), a rozvíjet oborovědidaktický či transdidaktický diskurz, tj. kultivovat didaktický (meta)jazyk a způsob uvažování nad edukačními fenomény. I alterace se odehrává ve dvou krocích: 1. posouzení kvality výukové situace a 2 . návrh alterace.

\section{Posouzení kvality}

V prvním kroku je analyzovaná situace kategorizována na škále kvality a tato kategorizace je zdůvodněna. Metodika 3A staví na premise, že každé hodnocení kvality výuky se při detailním rozboru prokazuje jako relativní: vyplývá z celé řady souvislostí, v nichž každá změna hlediska může vést $k$ posunu na hodnotící škále. Proto lze bez větší licence tvrdit, že ke každé výukové situaci lze navrhnout zlepšující alteraci; samotný fakt, že bylo objeveno a zdůvodněno zlepšení (zlepšující alterace), tedy nelze považovat za absolutní indikátor nízké kvality původní výukové situace. Přesto má smysl odhadnout míru či stupeň kvality posuzované situace, protože to vede k požadavku tento odhad zdůvodnit. Pro tento účel byla vyvinuta škála, na které může být výuková situace hodnotově kategorizována jako selhávajicí, nerozvinutá, podnětná či rozvijejicí (např. Janík et al., 2013, s. 241). Stručnou ukázku určení stupně kvality spolu s krátkým zdůvodněním poskytuje následující výňatek z kazuistiky:

Zkoumanou výukovou situaci lze hodnotit jako nerozvinutou (srov. tamtéż, s. 237). Pozornost žákỉ je smérována k motivaci (prevlek učitelky, využití nahrávky na $C D k$ navozeni atmosféry), avšak není využita príležitost strukturovaně se zaměrit na vztah objektu, materiálu (ze kterého je vytvořen) a kličové charakteristiky tohoto materiálu (tendence $k$ rozkladu). $Z$ tohoto divvodu lze o zkoumané výukové situaci uvažovat jako o instanci $t z v$. utajeného poznáváni. ${ }^{17}$

\section{Návrh alterace a její přezkoumání}

Druhým krokem v alteraci je navržení, zdůvodnění a diskuse takové hypotetické změny $\mathrm{v}$ realizaci výukové situace, která by vedla ke zvýšení kvality výukové situace. Jde tak vlastně o pokračování a prohloubení analýzy, nebot́ zde přichází na řadu hodnotová komparace pưvodní a navrhované varianty. Tento postup je ilustrován následující částí kazuistiky:

$V$ prípadě zkoumané výukové situace se jako alterace nabizi zpresnèni práce s pojmy, tj. explicitni pojmenováni a provázáni 1. označeni objektulodpadku, 2. materiálu, z něhož je vyroben, a 3. doby, po kterou se v biotopu rybník samovolné rozloži (naprr. s oporou o grafické zpracování). Takové lepši

\footnotetext{
${ }^{17}$ Utajené poznáváni je kategorii didaktického formalismu, která je charakteristická tím, že „úlohy neposkytuji dostatečnou príležitost $k$ hlubšimu porozumění instrumentálni praxi prìslušné disciplíny a k nezbytnému zvládnutí jeji terminologie“ (Slavík et al., 2017, s. 386). Jinými slovy, žáci jsou v takové situaci nedostatečně kognitivnè aktivizováni, jejich angažovanost ve výnkové situaci je zjevná, avšak povrchní.
} 
Tab. 2. Explicitní struktura pojmů v alteraci

\begin{tabular}{|c|c|c|}
\hline Objekt/odpadek & Materiál & $\begin{array}{c}\text { Doba samovolného rozpadu v podminkách } \\
\text { danébo biotopu }\end{array}$ \\
\hline ohryzek & rostlinná tkáň & $d n y$ \\
\hline noviny & papír & týdny \\
\hline plechovka & kov & desitky let \\
\hline sáček & mikroten & stovky let \\
\hline PET láhev & plast & stovky let \\
\hline sklenice & sklo & stovky tisic let \\
\hline
\end{tabular}

provázáni ve svém di̊sledku zvýsí integritu výukové situace (viz výse), nebot'se tím dosábne toho, aby žákovské zkušenosti, výbèr obsahu a žákovské ćinnosti byly v co nejlepšim možném souladu s formulovanými (anebo implicitnimi) cíli. Navržená alterace tedy spočivá jednak $v$ explicitnim poukazu na triádu objekt-materiál-vlastnost, jednak $v$ navýseni počtu téchto triád, aby kličový vztah lépe vynikl (tab. 2) a mobla $k$ nému být směrována pozornost žákü, a jednak v explicitnim poukazu na vztah délky rozpadu a efektu nahromadèni odpadküv prostředi, cožje (ve zkoumané výukové situaci) nepojmenovaným disledkem „trvanlivosti“ materiáli.

Zpřesnèni pojmů a lepši rozlišeni pojmenováni objektulodpadku a jejich vlastnosti (materiálů, z nichž jsou vyrobeny) by žákưm umožnilo lépe analyticky uvažovat a abstrahovat ve vztahu $k$ ochraně životniho prostředi (na príkladu konkrétního biotopu), prípadně odpadovému hospodařeni (napr. recyklace). Zároveň by méla výuková situace lépe nakročeno k efektivnimu propojeni kognitivni dimenze oborových cílu (rozvijeni oborového pojmoslovi a znalosti procesu dekompozice, degradace, eroze) s afektivnim (etickým) rozmèrem reflektovaným v proenvironmentálních postojich.

\subsection{Potenciál OZP}

Didaktické kazuistiky lze chápat jako unikátní nástroj pro nahlížení na podstatná místa kurikula z hlediska toho, jak jsou zprostředkována $\mathrm{v}$ reálných situacích ve školních třídách. Jejich hodnota dle našeho soudu spočívá právě v propojení kurikulárního uvažování (jako promýšlení strukturace vzdělávacích obsahů a cílů) s nahlížením na reálné procesy ve výuce a na to, jak se v nich „dařri“ kultivovat (oborové, tj. obsahové) vědění žáků. Máme za to, že právě tohoto propojení je v jiných výzkumných přístupech dosahováno jen velmi omezeně, nebot' ty se zaměřují bud' na obsah vzdělávání (výzkumy kurikula), nebo na jeho realizační formu (tzv. povrchové struktury výuky, sight structures, Sichtstrukturen - Oser \& Patry, 1990).

Výše zmíněná „mezera“ mezi popisem a hodnocením výuky je v OZP přemostěna porovnáváním realizované výuky $s$ její myšlenou variantou, která má být navržena $s$ didaktickým porozuměním hloubkové sémanticko-logické strukturaci obsahu v dané výukové situaci. Tím se naskýtá prŕležitost promýšlet funkční vztahy 
mezi obsahem, který mají žáci ve výuce zvládnout a porozumět mu, a reálně pozorovanými postupy vyučování a učení. Sémanticko-logickou strukturu obsahu lze totiž chápat jako jedinou funkční spojnici mezi jednáním, vnímáním a jazykem, resp. myšlením. Je tedy nepominutelným ohniskem všech vztahů, které spojují vzdělávací obsah - situovaný v intersubjektivním prostoru kultury - s jednáním, myšlením a komunikačními aktivitami subjektu, tj. každého jednotlivého žáka (srov. Janík \& Slavík, 2009).

OZP tím vlastně analyticky rozebírá a rozvíjí obsahově orientované pojetí príležitostí $k$ učení. Učební prostředí chápané jako intersubjektivní „kulturní pole“ - žákům poskytuje př́ležitosti, aby porozuměli vzdělávacímu obsahu na podkladě toho, že se o něm mají dorozumět. Jak upozorňuje Klafki (2000) a s odkazem na něj Hopmann (2007), Gruschka (2013), Midtsundstad (2015) a další, výzkumy zaměřené na procesy dorozumívání a utváření porozumění určitému obsahu jsou v pravém smyslu výzkumy vzdělávání. Je-li vzdělávání ústř̌ední kategorií didaktiky, pak jde o výzkumy didaktické. A má-li se didaktický výzkum zabývat procesem utvárení porozumění, pak se neobejde bez zobecňování založeného na studiu sémantizace: utváření významové a logické struktury obsahu v intersubjektivním prostředí.

\subsection{Limity OZP}

Didaktické kazuistiky - a př́padové studie ve vzdělávání obecně - nemají v českém prostoru dlouhou metodologickou tradici; za legitimní nástroj pro budování obecného didaktického vědění začínají být považovány teprve $\mathrm{v}$ poslední době (srov. Mareš, 2015). Přijmeme-li totiž tezi o tom, že každá vyučovací hodina je ve své realizaci unikátním, neopakovatelným a nesrovnatelným pedagogickým dílem, pak je třeba hledat netriviálni způsoby, jakými didaktické vědění zkonstruované nad jednou výukovou situací abstrahovat a učinit užitečným pro obecné uvažování o výuce per se.

Jednou z možností, jak řešit problém zobecnění z případových studií, je analytické zobecñováni (Yin, 2014, s. 98-102), založené na teoretickém konstruktu replikace, které pracuje s hypotetickými předpoklady vztaženými $\mathrm{k}$ předmětu pozorování a následně s aplikací teoretických konstruktů na další podobné př́ípady. Analýza konkrétní výuky by dospěla k návrhu teoretického konstruktu, který by vyhovoval danému př́padu a zároveň by měl předpoklady $\mathrm{k}$ (transdidaktickému) zobecnění na další případy (srov. Slavík et al., 2017, s. 352-355).

Zobecnění, s nímž pracuje OZP, je založeno na sémanticko-logické strukturaci obsahu, ale musí se vyrovnat $s$ jedinečným „zrealizováním“ v konkrétní výuce (srov. pojem realizované kurikulum - Průcha, 1997, s. 246). Stanovení kvality této „realizace“ obsahu závisí na co nejpřiléhavější interpretaci a pressném výběru těch momentů výuky, jejichž př́padná změna by vedla $k$ lepší integritě výuky. Je nasnadě, že pro tento úkol musí být výzkumník vybaven jak odpovídajícími ontodidaktickými znalosti (vhledem do kulturního kontextu, 
resp. oboru), tak znalostmi psychodidaktickými (dovedností přistupovat k obsahu z pozice žáka). Zdaleka totiž nejde o „vyřešení" problému nalezením ideálního výkladu struktury. Jde přece o to, aby se $\mathrm{k}$ tomuto výkladu (s porozuměním) propracovali sami žáci, a to prostřednictvím učebních úloh, které je povedou ke snaze dorozumět se. Proto každé zobecnění v didaktické kazuistice je zároveň provázeno nárokem na respekt $\mathrm{k}$ jedinečným řešením a $\mathrm{k}$ dynamice sociokognitivního dialogu při utváření učebního prostředí.

K etablování takových nových metodologických postupů v českém pedagogickém či didaktickém diskurzu ale vede dlouhá cesta, nebot' je žádoucí motivovat jejich proponenty $\mathrm{k}$ podrobnému zdůvodňování a osvětlování př́slušných metodologických souvislostí (srov. Dvořák et al., 2016).

\section{SPOLEČNé cíle KVS a OZP}

\section{A ODLIŠNÉ CESTY JEJICH \\ DOSAHOVÁNÍ}

Jak vyplývá z prredstavení obou diskutovaných prístupů (výše), príistupy stavějící na KVS i OZP spadají do proudu výzkumu kvality výuky (výzkumu kvality procesů vyučování a učení). Jsou tedy př́iležitostí $\mathrm{k}$ budování didaktického vědění, které je postaveno na empirickém nahlížení do reálné výuky. Lze je chápat jako v jistém smyslu systematické, analytické, nadoborové a mající ambici budovat takové didaktické vědění, které přispěje $\mathrm{k}$ co nejhlubšímu porozumění procesům vyučování a učení ve výuce.
Oba prístupy jsou bytostně didaktické, nebot se zaměřují na porozumění způsobům, jakými je utváreno učebni prostředi (learning environment), jako kulturní prostor, ve kterém jsou žákům nabízeny príležitosti $k$ učení (opportunities to learn). Stranou tak do jisté míry nechávají výsledky učeni ve smyslu kvantitativních dat atraktivních pro sociologii vzdělávání, či ve smyslu obsahů žákovských myslí, jež jsou předmětem zájmu pedagogické psychologie.

Oba prrístupy jsou také didaktické $\mathrm{v}$ tom ohledu, že jsou motivovány snahou přispět ke zvyšování kvality vzdělávání a tím jsou (in)formativní pro učitelské vzdělávání. Hiebert a kol. (2003, s. 3) označují zlepšení praktik učitelů za „netriviální benefit mezinárodních a komparativních výzkumů výuky" a Janík a kol. (2013, s. 11) uvádějí, že „smyslem hodnocení kvality výuky je možnost jejího zlepšování...". Cesty, kterými chtějí k tomuto zlepšování dospět, jsou však v jistém smyslu diametrálně odlišné.

Jak také vyplývá z dosavadního výkladu, oběma rozdílným prístupům by bylo možné přiřadit (poněkud extrémní) polohu na některé z obecných dichotomií:

KVS lze vnímat jako výzkumný přístup kvantitativní. $\mathrm{V}$ ideálním př́padě mají ambici formulovat obecněji platné závěry, pracují na principu kategorizace desítek tisíc analyzovaných jednotek a lze na ně uplatňovat logiku zobecňování z výběrového souboru (vzorku) na základní soubor (populaci). Oproti tomu OZP staví spíše na postupech kvalitativního výzkumu; vyhledává a analyzuje kvalitativně zá- 
važné incidenty, interpretuje a konstruuje jejich kurikulární význam a učební potenciál. S ohledem na jejich základní perspektivu by tedy bylo možné je označovat pojmy nomotetický př́stup, resp. přístup ideografický.

$\mathrm{V}$ souladu s pozitivistickou tradicí kvantitativního výzkumu lze na KVS pohlížet jako na snahu dokumentovat objektivni, nebo alespoň skrze statistické procedury (inter-coder reliability) objektivizovaný pohled na edukační realitu. Dokladem toho je pozornost, jaká byla ve videostudii TIMSS věnována objektivizaci (nejen) postupů uvnitř mezinárodního týmu kódovatelů (Hiebert et al., 2003, s. 161-172). Naproti tomu pro OZP je rozhodující zaostření na procesy transformace obsahu, která se v principu odehrává v intersubjektivním prostoru učebního prostředí (Slavík et al., 2017, s. 183). Objektivizace je tu vždy zřetelně závislá na interpretování významové a logické výstavby obsahu učebního prostředí. Má tedy obdobnou povahu jako při obsahové analýze textů.

KVS lze chápat jako prístup $\mathrm{v}$ první řadě deduktivní; staví na kategoriálních systémech, které jsou stanoveny na základě teoretického chápání zkoumaného problému, prrípadně na předchozí empirické zkušenosti. Pomocí těchto kategoriálních systémů je pak pozorovaná edukační realita kvantifikována. Oproti tomu analýza v OZP je v principu induktivní; celek (sémanticko-logická struktura obsahu) je konstruován na základě pozorování interakce mezi učitelem a žáky a může být nahlédnut teprve tehdy, až je analýza ukončena.
$\mathrm{Na}$ rozdíl mezi KVS a OZP lze také nahlízet $s$ vědomím rozdílů mezi substanční a relační povahou vědění a vědy (srov. Slavík et al., 2017, s. 20-21). Substančně pojatá věda kategorizuje objekty podle jejich vlastností a tím přispívá $\mathrm{k}$ poznání toho, jak se svět jeví. KVS v tomto duchu trrídí vyučovací hodiny či jejich části podle stanovených kritérií, a má tak blízko k přírodovědným oborům. Naproti tomu relační pojetí vědy je postaveno na interpretování významových a logických vztahů, a bere tak $\mathrm{v}$ potaz různé varianty uchopení obsahu (tj. nahlíží na jeho transformaci v intersubjektivním prostoru mezi učitelem a žáky). Má tedy blízko $\mathrm{k}$ oborům socio-humanitním.

Některé př́stupy KVS byly také charakteristické snahou záměrně setrvat na $d e-$ skriptivní rovině uvažování o školní výuce (srov. ambice realizovat základni výzkum ve vzdělávání, viz výše). KVS má v tomto pojetí nabízet primárně neutrální - weberovsky nehodnotící - pohled na výuku. To odpovídá substančnímu pojetí vědění v KVS: identifikace a popis jednotlivých determinant totiž nevedou k hodnotovým soudům. Oproti tomu v OZP je hodnocení kvality výuky hlavním cílem analýzy. Slavík et al. (2017, s. 178) k tomu uvádějí: „Nejde [...] jen o to výuku analyzovat, ale návazně i vymezit a určit její kvality s výhledem na zdůvodněné zlepšování profesní činnosti učitelů. Zjištování vzdělávací kvality se samozřejmě neobejde bez hodnocení, protože jen prostřednictvím hodnotové komparace lze identifikovat míru realizované hodnoty a rozlišovat lepši výuku od výuky horši." 
Oba př́stupy se tedy zaměřují na identifikaci invariantů, které lze chápat jako konstantní momenty výuky a jejichž uspořádání je rozhodující pro kvalitu výuky. Povahu těchto invariantů však vnímají odlišně. KVS hledají účelné interakční vzorce, procedury, metody práce, organizační formy, tj. způsoby jednání ve výuce. Oproti tomu OZP vidí „komparační konstantu“ jinde - v sémanticko-logické struktuře vzdělávacího obsahu, která je východiskem pro učitele konstruujícího učební úlohy a které jsou veškeré způsoby jednání ve výuce podřízeny.

Oba př́istupy, jak bylo řečeno výše, mají ambici posuzovat kvalitu výuky, což obnáší hledání a vysvětlování kauzálních vazeb mezi charakteristikami výuky a utvářením vědění žáků. KVS k tomu účelu korelují výukový vzorec $s$ výkony žáků v didaktických testech. To jim umožňuje identifikovat „fungujíci" vzorce a postupy. OZP komparuje a hodnotí různé varianty realizace téhož obsahu s cílem objevit optimální „vzorec“ pro danou „strukturaci obsahu“. Opírá se pritom o princip analogického posuzování, tj. „odhadování vnitrnich učebních efektů výuky z její vnějš́ podoby" (Slavík et al., 2017, s. 332).

Technicky se oba prístupy liší i pohledem na analyzované celky. V KVS je primárně analyzována vyučovací hodina, která je technicky vymezena zpravidla 45 minutovým rámcem, a implicitně se pracuje s tezí, že vyučovací hodiny jsou srovnatelné. Tím je míněno, že lze provádět (relativně snadnou) komparaci aspektů (vlastností) pozorovaných vyučovacích hodin, tj. zaměřit se na to, co mají společné a v čem se liší. Analyzované jednotky (např. desetisekundové intervaly) jsou si inherentně rovny. Naproti tomu v OZP je analyzována výuková situace, která je vymezena jako obsahově smysluplný celek. Tím se naznačuje, že určité okamžiky jsou ve výuce didakticky důležitější než jiné. To je sice na první pohled banální konstatování, ale pro porovnávání hodin má závažné důsledky, protože přenáši pozornost od kategorizovaných popisných vlastností výuky $\mathrm{k}$ transformačnímu procesu, jímž se obsah ve výuce stává součástí žákovských dispozic.

\section{Problém ne-obsahovosti}

Na klíčový rozdíl mezi KVS a OZP, který má tato studie ambici ozřejmit, upozorňujeme s oporou o rozlišení pojmů predem strukturovaná reflexe a následné strukturovaná reflexe (napry. Slavík et al., 2015). KVS přinášejí velmi cenné poznatky o pravidelnostech ve výskytu jevů, které vyučovací hodiny sdílejí, tj. vlastností vzdělávacího obsahu. „Sítem“ pozornosti (předem stanovených kategoriálních systémů) KVS však „propadává“" to, co je v každé hodině jiné, unikátní a neopakovatelné, tj. samotné intersubjektivni konstruováni vzdèlávacího obsa$h u$. Právě proto, že způsob intersubjektivního konstruování obsahu prostřednictvím žákovského řešení úloh je v každé vyučovací hodině jiný, není možné préedem (před samotným pozorováním výuky $v$ aktuálním kontextu) konstruovat kategorie pro zachycení obsahu v jeho dynamice. ${ }^{18}$

\footnotetext{
${ }^{18}$ Zatímco základní sémanticko-logická struktura obsahu je v principu víceméně konstantní (zakotvená v oboru a v kurikulu), její aktualizace př̌i řešení úloh v konkrétní realizaci je vždy jedinečná.
} 
Pohled na výuku, který nabízejí KVS, je tedy v pravém slova smyslu (avšak nikoli pejorativně) obsahově vyprázdněný. Toto mijeni se s obsahem lze považovat za kritické místo KVS. Je sice možné propojit videodata $s$ daty o výsledcích učení žáků, což je cenné, nebot účelné statistické procedury dokážou odhalit souvislosti a závislosti, jež nejsou běžné učitelské zkušenosti dostupné jinak než ve velmi prchavé anekdotické formě. Přesto však KVS nemohou přispět $\mathrm{k}$ formulaci jiných doporučení či metodik než obecně pedagogických. Tyto metodiky však trpí právě tím, že př̀i jejich formulaci nebylo (a nemohlo být) bráno v úvahu právě to, co výjimečně zajímá samotné učitele: průběh transformace obsahu, během níž, obrazně řečeno, obsah vstupuje do mysli a jednání žáků. Spolu s transformací obsahu uniká pozornosti mnoho závažných aspektů výuky, které rozhodují o její př́nosnosti pro žáky, resp. o její vzdělávací kvalitě.

Jinými slovy, KVS a OZP se nepohybují na stejné úrovni zobecnění; OZP zachovává ohled na sémanticko-logickou strukturu vzdělávacího obsahu a upíná pozornost ke vztahu mezi touto strukturou a způsobem utváření učebního prostř̌edí $\mathrm{v}$ učebních úlohách (př́stup relačni). $\mathrm{Na}$ proti tomu KVS rezignuje na uchopení struktury obsahu i jejího utváření $\mathrm{v}$ učebních úlohách a zaměřuje se na sledování kategorizovaných vlastností způsobů utváŕení učebního prostř̌edí (přístup substančni). Pojem vyprazdňování obsahu tedy v tomto specifickém pojetí odkazuje $\mathrm{k}$ faktu, že na určité úrovni abstrakce se ztrácí zřetel ke způsobům mentalizace oborového ob- sahu v intersubjektivním prostředí výuky, a tím $\mathrm{k}$ žákovskému utváření zkušenosti (Slavík et al. 2017, s. 327).

Naši klíčovou tezi lze formulovat takto: Chceme-li porozumét tomu, jak (kvalitné) se utvárí učebni prostředi ve výuce, je nutné rekonstruovat proces transformace obsahu současně jak z hlediska príslušného oboru (resp. oblasti kultury), tj. ontodidakticky, tak z hlediska žákovských dispozic, tj. psychodidakticky. To znamená interpretovat $\mathrm{z}$ „povrchové“ podoby výuky, tedy z jejího popisu, „hloubkové“ procesy sémantizace, které podmiňují kvalitu výuky. Jinak řečeno, pokusit se vyložit, jak se pozorovaný stav výuky může podílet na utváření významů v mysli žáka. To se ovšem neobejde bez detailního prozkoumání konkrétních způsobů, jimiž se obsah výuky stává se pro žáka srozumitelným a př́stupným pro dorozumění s druhými lidmi. Německý didaktik Hopmann (2007, s. 117) podotýká, že „[...] propojení obsahu a významu [...] je vynořující se zkušeností, která je vždy situovaná $\mathrm{v}$ jedinečných momentech a interakcích“. To, oč se v OZP jedná, jsou právě ony ,jedinečné momenty a interakce“, které nelze zkoumat bez zvláštního zřetele $\mathrm{k}$ situačním souvislostem výuky.

Nahlédneme-li pro paralelu do lingvistiky, můžeme připomenout, že plný význam věty je možné rekonstruovat teprve tehdy, až je celá utvořena $\mathrm{v}$ konkrétním situačním kontextu, a pouze tehdy, rozumíme-li jejím neviditelným („hlubokým") významovým a logickým souvislostem ukotveným v jazyce. Slovy Peregrina (2003, s. 133), „význam výrazu nemůžeme ,přečist' z jeho povrchové struktury“. Též 
rekonstrukci a didaktický výklad sémantizačního potenciálu výuky lze uskutečnit teprve poté, co byla výuka realizována, a pouze na podkladě „hloubkové“ interpretace vztahů mezi základní sémanticko-logickou strukturou obsahu a konkrétními aktivitami žáků a učitele ve výuce. (Př́kladem takového postupu byla výše uvedená ukázka z jedné kazuistiky vytvořené metodikou 3A.)

Strukturovat reflexi toho, jak se obsah v konkrétní výukové situaci transformoval, má tedy smysl až následně, tj. poté, co výuka proběhla. OZP proto využívá tzv. následně strukturovanou reflexi $\mathrm{k}$ tomu, aby analyzoval konkrétní realizaci vzdělávacího obsahu v intersubjektivním prostoru učebního prostředí. Obsah zde „nepropadá“ sítem předem stanovených kategorií, ale naopak je zachycen nejprve v síti své sémanticko-logické struktury (určené kurikulem vzdělávacího oboru) a poté na základě rekurzivního zkoumání vztahů mezi ní a konkrétními podobami výuky. Tento postup je tedy založen na analýze vztahů mezi obsahem, resp. učivem, a konkrétními způsoby jeho uplatnění ve výuce. Tím může přispívat k rozvoji (učitelské) schopnosti analyzovat učivo s ohledem na jeho ontodidaktické a psychodidaktické souvislosti.

\section{MísTO ZÁVĚRU: O DOPADECH VÝZKUMNÝCH PŘÍSTUPU゚ NA PŘíPRAVU UČITELŮ...}

Smyslem tohoto textu bylo kontrastivně představit dva př́stupy ke zkoumání výuky, které oba ve svém důsledku přiná- šejí velmi cenné, avšak principiálně odlišné poznání o procesech vyučování a učení. Kvantitativní videostudie (KVS) - svou povahou kvantitativní, deduktivní a predem strukturujicí - dokážou generovat bohaté poznání o kontextech, formách a průběhu výuky (nikoli nepodobné sportovním statistikám v nejlepším slova smyslu); poznání, jehož síla spočívá v komparativním (mezinárodním, mezipředmětovém) náhledu. Dokážou také nabídnout bohaté metodické inspirace teoretikům, vzdělavatelům učitelů i samotným praktikujícím učitelům. Nedokážou však čočky svých kamer zaostřit na to, co je třeba ve výuce považovat za klíčové z pohledu otázky, „co se mají žáci z výuky dozvědět", tj. na dynamiku procesu, $v$ němž se kurikulární obsah transformuje do podoby žákovských znalostí, dovedností, kompetencí ad. Nabídli jsme $\mathrm{k}$ diskusi tezi, že redukce výzkumných strategií jen na předem strukturované postupy by mohla vést $\mathrm{k}$ nebezpečnému vyprázdněni obsahu z edukačního výzkumu. Ještě horší důsledek však může mít v tom, že by vedla $\mathrm{k}$ vyprázdnění obsahu z celého vzdělávacího diskurzu. $Z$ různých náznaků se lze domnívat, a koneckonců i celé zaměření tohoto monotematického čísla tomu napovídá, že vyprazdňování obsahu ze vzdělávacího diskurzu se stává realitou. Za jeden z jeho př́znaků by bylo možné považovat převahu zájmu o vzdèlávaci metody nad zájmem o vzdélávací obsah $\mathrm{v}$ určité kultuře vyučování a učení (srov. Slavík \& Najvar, 2016).

Oproti tomu obsahově zaměřený př́ístup (OZP) - svou povahou kvalitativní, induktivní a následnè strukturujicí - obsah sítem své analýzy „propadnout nene- 
chává“. Svým zaměřením na obsahovost je blízký učitelskému uvažování o výuce a $\mathrm{z}$ individuálních ohlasů lze soudit, že někteří učitelé $\mathrm{v}$ praxi $\mathrm{v}$ něm vidí vítaný odklon od dosavadního často velmi formalistického hodnocení kvality výuky. Je třeba ale hledat další cesty jeho rozvíjení, nebot' bude třeba solidně propracované metodiky zobecňování poznatků z didaktických kazuistik (např. $\mathrm{v}$ paralele $\mathrm{k}$ umělecké kritice), aby se dařilo obsahovost (nahliženou kupř. skrze integritu výuky) udržet jako jeden z principů hodnocení výuky.

Oba představené výzkumné př́stupy nelze vnímat jen jako prístupy k výzkumu vzdělávání. Svými východisky a zejména povahou vědění, jež generují, představují především rozdílná pojetí vzdèlávání, a jako takové mají př́mé dopady na pojetí vzdělávání ucitteli. Lze to ilustrovat komentárem Stiglera a Hieberta, kteří na podporu videostudie TIMSS explicitně uvádějí: „Zlepšování kulturních skriptů je něco podstatně jiného než zlepšování dovedností individuálních učitelů. Pokud je ale vyučování kulturní aktivitou, je třeba právě to první. Nezáleží na tom, jak dobř́i učitelé jsou, vždy budou jen tak efektivní, jako jsou skripty, které používají. Chceme-li dlouhodobě zlepšit vyučování, musíme vylepšit skripty. “ (Stigler \& Hiebert, 1998, s. 6)

To je zřejmě v souladu s náhledem na učitelské vzdělávání, jak jej utváŕí výzkumný proud označovaný $\mathrm{v}$ této studii jako KVS: Ucitelé se maji seznámit s metodickými postupy, které průkaznè vedou $k$ "lepšim "výsledkưm żákư, a ty ve své výuce účlnè aplikovat.

Oproti tomu pojetí vzdělávání dle OZP evidentně směruje naopak právě $\mathrm{k}$ podpoře rozvíjení individuálních učitelských dispozic. Učitel jako tvořivý profesionál - má-li obstát ve své klíčové didaktické úloze tvůrce smysluplných učebních úloh - musí nejprve do hloubky porozumět ontodidaktickým a psychodidaktickým souvislostem každého učiva, nad kterým se se svými žáky setkává. Teprve potom může být úspěšným př̀i utváření optimálního učebního prostředí pro žáky.

Děkuji editorưm č́sla a obèma anonymnim recenzentüm za cennou zpètnou vazbu $k$ rukopisu studie. Stala se východiskem pro úpra-

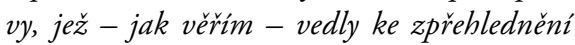
a zjednodušeni linie výkladu.

\section{Literatura}

Brandt, R. (1992). On research on teaching: A conversation with Lee Shulman. Educational Leadership, 49(7), 14-19.

Buty, C., Tiberghien, A., \& Le Marechal, J.-F. (2004). Learning hypotheses and an associated tool to design and to analyse teaching-learning sequences. International Journal of Science Education, 26(5), 579-604.

Clarke, D. J., Emanuelsson, J., Jablonka, E., \& Mok, I. A. C. (Eds.). (2006). Making connections: Comparing mathematics classrooms around the world. Rotterdam/Taipei: Sense Publishers.

Češková, T., \& Knecht, P. (2016). Analýza problémově orientovaných výukových situací ve výuce prírodovědy. Orbis scholae, 10(2), 93-115. 
Dvořák, D., et al. (2016). Redakční poznámka k textu M. Ruska, J. Slavíka a P. Najvara. Orbis scholae, 10(2), 159-171.

Flanders, N. A. (1970). Analyzing teaching behavior. Reading: Addison-Wesley.

Gavora, P. et al. (1988). Pedagogická komunikácia v základnej škole. Bratislava: Veda.

Givvin, K., Hiebert, J., Jacobs, J., Hollingworth, H., \& Gallimore, R. (2005). Are there national patterns of teaching? Evidence from the TIMSS 1999 video study. Comparative Education Review, 49(3), 311-343.

Greger, D., Janík, T., Kotásek, J., Maňák, J., \& Walterová, E. (2006). Charakteristika Centra základního výzkumu školního vzdělávání. Orbis scholae, $0(1), 5-12$.

Gruschka, A. (2013). Verstehen fördern, Verstehen verhindern. In K. P. Liessmann \& K. Lacina (Eds.), Sackgassen der Bildungsreform (s. 25-36). Wien: Facultas.

Hiebert, J., Gallimore, R., Garnier, K., Givvin, K., Hollingsworth, J., Jacobs, J., ... Stigler, J. (2003). Teaching mathematics in seven countries. Results from the TIMSS 1999 video study. Washington D.C.: USA Department of Education.

Hopmann, T. S. (2007). Restrained teaching: The common core of Didaktik. European Educational Research Journal, 6(2), 109-124.

Horká, H. (2000). Výchova pro 21. století. Koncepce globálni výchovy v podminkách české školy. Brno: Paido.

Hugener, I., Pauli, C., Reusser, K., Lipowsky, F., Rakoczy, K., \& Klieme, E. (2008). Teaching patterns and learning quality in Swiss and German mathematics lessons. Learning and Instruction, 19(1), 66-78.

Janík, T. (2009). Výzkum výuky: historický vývoj. In M. Janíková \& K. Vlčková (Eds.), Výzkum výnky: tematické oblasti, výzkumné prístupy a metody (s. 23-43). Brno: Paido.

Janík, T., \& Miková, M. (2006). Videostudie: výzkum výnky založený na analýze videozázna$m u$. Brno: Paido.

Janík, T., \& Slavík, J. (2009). Obsah, subjekt a intersubjektivita v oborových didaktikách. Pedagogika, 59(2), 116-135.

Janík, T., Slavík, J., Mužík, V., Trna, J., Janko, T., Lokajičková, V., ... Zlatníček, P. (2013). Kvalita (ve) vzdèláváni: obsahově zaměrený prìstup ke zkoumání a zlepšováni výuky. Brno: Masarykova univerzita.

Klafki, W. (2000). The significance of classical theories of Bildung for a contemporary concept of Allgemeinbildung. In I. Westbury, K. Riquarts \& T. S. Hopmann (Eds.), Teaching as a reflective practice. The German Didaktik tradition (s. 85-107). Mahwah: Erlbaum.

Laborde, C. (1997). Affronter la complexit'e des situations d'apprentissage de math'ematiques en classe - D'efis et tentatives. Didaskalia, 10, 99-112.

Lefstein, A., \& Snell, J. (2014). Better than best practice: Developing teaching and learning through dialogue. London: Routledge.

Mareš, J. (Ed). (1981). Interakce učitel-žáci a učitel-studenti. Hradec Králové: Pedagogická fakulta UHK. 
Mareš, J. (Ed). (1988). Pedagogická interakce a komunikace. Hradec Králové: Pedagogická fakulta UHK.

Mareš, J. (2015). Tvorba př́padových studií pro výzkumné účely. Pedagogika, 65(2), 113-142. Midtsundstad, J. H. (2015). Bildung - At risk in school organisations? In S. Hillen \& C. Aprea (Eds.), Instrumentalism in education - where is Bildung left? (s. 29-41). Münster: Waxmann.

Najvar, P., Najvarová, V., Janík, T. \& Šebestová, S. (2011). Videostudie v pedagogickém výzku$m u$. Brno: Paido.

Oser, F., \& Patry, J.-L. (1990). Choreographien unterrichtlichen Lernens. Basismodelle des Unterrichts. Fribourg: Universität Fribourg.

Peregrin, J. (2003). Úvod do teoretické sémantiky. Praha: Karolinum.

Pospísilová, L. (2012). Př́ležitosti k rozvijení čtenář́sé gramotnosti na 1. stupni ZŠ. (Diplomová práce). Brno: Masarykova univerzita.

Průcha, J. (1997). Moderni pedagogika. Praha: Portál.

Rámcový vzdèlávaci program pro základni vzdèláváni. (2016). Praha: Národní ústav pro vzdělávání.

Roth, K. J., Druker, S. L., Garnier, H., Lemmens, M., Chen, C., Kawanaka, T., ... Gallimore, R. (2006). Teaching science in five countries: Results from the TIMSS 1999 video study. Washington, D.C.: U.S. Department of Education.

Seidel, T., \& Prenzel, M. (2006). Stability of teaching patterns in physics instruction: Findings from a video study. Learning and Instruction, 16(3), 228-240.

Seidel, T., Prenzel, M., \& Kobarg, M. (Eds.). (2005). How to run a video study: Technical report of the IPN Video Study. Münster: Waxmann Verlag.

Shulman, L. S. (1996). ,Just in case...": Reflections on learning from experience. In J. A. Colbert, P. Desberg \& K. Trimble (Eds.), The case for education: Contemporary approaches for using case methods (s. 461-482). Boston: Allyn \& Bacon.

Slavík, J. (1996). Pedagogické dílo a reflektování jeho významů a hodnot (Sémiologické aspekty reflektivní praxe ve výchově). In J. Mareš, J. Slavík, T. Svatoš \& V. Švec, Učitelovo pojetí výuky (s. 28-45). Brno: Masarykova univerzita.

Slavík, J., Lukavský, J., Najvar, P., \& Janík, T. (2015). Profesní soud o kvalitě výuky: předem a následně strukturovaná reflexe. Pedagogika, 65(1), 5-33.

Slavík, J., \& Najvar, P. (2016). Editorial: Kultury vyučování a učení v oborech školního vzdělávání. Orbis scholae, 10(2), 7-14.

Slavík, J., Janík, T., Najvar, P., \& Knecht, P. (2017). Transdisciplinární didaktika: o učitelském sdílení znalostí a zvyšováni kvality výnky napríč obory. Brno: Masarykova univerzita.

Starý, K., \& Chvál, M. (2009). Kvalita a efektivita výuky: metodologické př́stupy. In M. Janíková \& K. Vlčková (Eds.), Výzkum výuky: tematické oblasti, výzkumné prístupy a metody (s. 63-81). Brno: Paido.

Stigler, J. W., Gonzales, P., Kawanaka, T., Knoll, S., \& Serrano, A. (1999). The TIMSS videotape classroom study: Methods and findings from an exploratory research project on eighthgrade mathematics instruction in Germany, Japan, and the United States. Washington, D.C.: Department of Education. 
Stigler, J. W., \& Hiebert, J. (1998). Teaching is a cultural activity. American Educator, 22(4), $4-11$.

Šed'ová, K., \& Šalamounová, Z. (2016). Dialogické vyučování jako realizace produktivní kultury vyučování a učení v literární výchově. Orbis scholae, 10(2), 47-69.

Weinert, F. E. (1997). Lernkultur im Wandel. In E. Beck, T. Guldimann \& M. Zutavern (Eds.), Lernkultur im Wandel. Tagungsband drei Schweizerischen Gesellschaft für Lehrerinenund Lehrerbildung und der Schweizerischen Gesellschaft für Bildungsforschung (s. 11-29). St. Gallen: UVK.

Willbergh, I. (2011). Mimetic Didaktik: Why „the medium is the message“ in teaching. In S. Hillen, T. Sturm \& I. Willbergh (Eds.), Challenges facing contemporary didactics: Diversity of students and the role of new media in teaching and learning (s. 157-167). Münster: Waxmann.

Yin, R. K. (2014). Case study research: Design and methods. Los Angeles: Sage.

Mgr. Petr Najuar, Ph.D.

Masarykova univerzita, Pedagogická fakulta, Institut výzkumu školního vzdèlávání a katedra primární pedagogiky;

e-mail:najvar@ped.muni.cz

NAJVAR, P. Investigation of (the quality) of Teaching: Two approaches compared

This article presents two antagonistic approaches to the study of educational processes in school teaching. One of them is what is known as the IVŠV video study of teaching as a $n$ instance of quantitative video-studies (KVS); this is an approach that uses deductive category systems to identify the content and form of teaching and learning, and also to produce quantifying generalisation applied e.g. to interactive models in teaching or the subject and subject-didactic specifics of teaching. The second is the content-orientated approach $(O Z P)$ to investigating and improving teaching; this is an approach based on an inductive technique in the identification of the content cores of teaching and in qualitative assessment of the didactic quality of teaching situations. These research approaches are then used to explain differences in the character of the didactic knowledge generated by techniques grounded in so-called pre-structured reflection, as compared with didactic understanding (knowledge), generated by so-called post-structured reflection on teaching.

Keywords: research into teaching, videostudy, content-orientated approach, analysis of teaching situations, pre-structured reflection, post-structured reflection. 